\title{
COVID-19 AND THE WAY FORWARD: A STORY OF LIVELIHOODS FROM COASTAL RURAL SUNDARBANS, WEST BENGAL
}

\author{
Sharanya Chattopadhyay \\ Research Scholar \\ Tata Institute of Social Sciences, Maharashtra, India \\ E-mail ID: Sharanya.3266@gmail.com \\ Contact: 8981775067
}

Abstract: Globally around 2 billion people ( $\sim 61 \%$ of the total world population) are engaged in informal sector, whereas the percentage rises to more than $80 \%$ in India (ILO, 2018). Since 25th March 2020, the COVID-19 outbreak and lockdown in India due the COVID-19 pandemic has created an atmosphere of extreme uncertainty and raised several questions. Global analysts have already suggested that, for many developing countries, the economic consequences could be more crippling and devastating than the disease itself. Livelihoods are vital means of making a living. The terminology Livelihood is not synonymous to mere income generation. It encompasses people's capabilities, assets and activities required to secure the necessities of life. Undoubtedly, globally COVID-19 has become an unprecedented shock; however, any kind of shock tends to reinforce the existing socioeconomic-political and environmental stresses, problems and inequalities. Therefore, there is a need to understand how and to what extent this pandemic has affected and going to affect the lives and livelihoods of a coastal rural community entirely dependent on rain-fed agriculture, small-scale fisheries (inland and marine) and other riverine as well as forest resources for their subsistence. This paper attempts to explore the impact of COVID-19 outbreak and lockdown the livelihood choices and daily lives in the coastal rural stretches of Indian Sundarbans delta region. This study incorporates a telephonic rapid assessment survey method to understand the impact of COVID-19; for assessing the minute detailing and pathways of livelihoods, this paper refers to findings from a questionnaire-based household survey of the concerned area carried out by the author herself. The findings support the argument that the shock of COVID-19 will further aggravate the preexisting socioeconomic issues. The long withstanding local problems as well as backwardness and COVID-19 are mutually reinforcing in nature; the social cost and economic cost of this pandemic is immense. Asset loss, changes in dietary pattern and consumption, increased indebtedness, increased dependence on natural resources are some of the major findings.

Keywords: COVID-19, Livelihood Diversity, Vulnerability, Indian Sundarbans 


\section{INTRODUCTION:}

On $31^{\text {st }}$ December 2019, the Country Office of World Health Organization (WHO) in the People's Republic of China picked up a media statement by the Wuhan Municipal Health Commission on cases of 'viral pneumonia' in Wuhan, People's Republic of China. Later, on $5^{\text {th }}$ January 2020 the first Disease Outbreak News Report was issued by WHO that significantly highlighted "WHO's recommendations on public health measures and surveillance of influenza and severe acute respiratory infections still apply"; it was followed by the official confirmation on Novel Coronavirus being the cause of outbreak on $9^{\text {th }}$ January 2020. Later on $11^{\text {th }}$ March 2020, COVID-19 was characterized as a Pandemic by WHO (WHO, 2020). Till now COVID-19 has caused a tremendous apathy across the globe with total 15.4 million confirmed cases and a death tally of 620 thousand worldwide. In Indian context, the figures for confirmed cases and death tally have touched 1.24 million and 29 thousand respectively (till 23rd July 2020). In the past few months, as COVID-19 has proliferated into such unprecedented dimensions, a strange obsession with figures and statistics has been observed. Unfortunately, beyond the discourse of infection curve, mortality rate and measures to contain the spread, there lies a grey area that deals with socio-economic aspect of COVID-19 and lockdown. Global analysts have already suggested that, for many developing countries, the economic consequences could be more crippling and devastating than the disease itself. Taking into account the uncertainty attached to magnitude of COVID19 further, an accurate assessment of the impact of COVID-19 on the economy is still not possible. But unarguably, there is and will be an economic downturn expected at the global level; trickling down to developing economies, this economic downturn can further exacerbate existing food insecurity, livelihood insecurity and vulnerability (Beltrami, 2020). Livelihoods are vital means of making a living. The terminology Livelihood is not synonymous to mere income generation. It encompasses people's capabilities, assets and activities required to secure the necessities of life. Undoubtedly, globally COVID-19 has become an unprecedented shock; however, any kind of shock tends to reinforce the existing socio-economic-political and environmental stresses, problems and inequalities. Therefore, there is a need to understand how and to what extent this pandemic has affected and going to affect the lives and livelihoods of different communities. In this study through a rapid assessment survey the livelihood issues of coastal rural community of Indian Sundarban delta Region have been explored. A preliminary report has been prepared on how a village community entirely dependent on rain-fed agriculture, small-scale fisheries (inland and 
marine) and other riverine as well as forest resources for their subsistence is coping up with the pandemic and lockdown.

\section{COVID-19 AND LIVELIHOOD}

The history of livelihood thinking as well as research can be traced back to monodisciplinary, sectoral perspectives offered by economists and geographers. "Livelihoods" is a highly flexible term; it can be found in most of the literature that deals with "people" in the form of livelihood approaches, perspectives, frameworks, and method. These relate to varied aspects, such as, occupations (farming, fishing livelihoods), locations (rural or urban livelihoods), social categories (gendered, age-defined, religion-defined livelihoods), patterns (sustainable and unsustainable livelihoods), directions (livelihood pathways, trajectories) and so on (Scoones, 2009: 172).

During the 1980s and 1990s, with the paradigm shift in the world scenario, the focus shifted to the real world. The whole discussion became "actor-oriented" in an attempt to understand the things from local perspective, i.e. the lived experiences and struggle of poor people themselves, without relying upon artificial divisions and complex categorizations. In 1992, Chambers and Conway's seminal paper on "sustainable rural livelihoods (SRL)" produced the most widely used definition of livelihood, which is as follows-

"A livelihood comprises the capabilities, assets (stores, resources, claims and access) and activities required for a means of living. A livelihood is sustainable when it can cope with and recover from stress and shocks, maintain or enhance its capabilities and assets, and provide sustainable livelihood opportunities for the next generation; and which contributes net benefits to other livelihoods at the local and global levels and in the short and long term" It has been stated that subsistence producers, small fishers and small farm wage laborers in the rural areas of low-income countries constitute over two thirds of the global poor and food insecure populations (FAO, 2014). Livelihoods among the rural population of tropical coastal communities often rely heavily on a range of natural resource dependent occupational sectors, such as agriculture, fisheries, and informal economic activities (i.e. small shops, transportation, etc.). The combination and type of household livelihood strategy mostly depend on particular season, access to the resource (whether fishing areas or farm land), access to capital, skill base, education and risk preference. While adapting to changing circumstances the coastal rural communities often face a nominal level of option for diversification; as a result, the alternative or secondary economic activity practiced by the communities are also extremely dominated by climatic and anthropogenic considerations 
(Pomeroy et al., 2006). Globally around 2 billion people ( $\sim 61 \%$ of the total world population) are engaged in informal sector, whereas the percentage rises to more than $80 \%$ in India (ILO, 2018). Workers engaged in vulnerable forms of employment are exposed to high levels of precariousness; they are more likely to be informally employed, have fewer chances of social engagement and are less likely to benefit from job security, regular incomes and access to social protection than their wage and salaried counterparts (ILO, 2017e). Worryingly, the significant progress achieved in the past in reducing vulnerable employment has essentially stalled since 2012 , with the rate remaining above $42 \%$ globally. In 2017 , almost 1.4 billion workers are estimated to be in vulnerable forms of employment, and every year an additional 17 million join them (ILO, 2018). As per the recent Periodic Labour Force Survey (PLFS), 2017-18, around 0.45 billion (47\%) adults are working in the country. Over half $(52 \%)$ of the workers are self-employed followed by casual workers $(25 \%)$ and the remaining are regular or salaried (23\%). Of these, the casual workers are the most vulnerable due to the irregular nature of their work and daily-wage payment based on their work schedules. The status of other workers also does not provide a great sight, as most of the selfemployed (96\%) were either own-account workers or unpaid family worker (sole workers), with only $4 \%$ constituting employers or entrepreneurs (PLFS, 2017-18). In an attempt to combat different types of shocks and stresses, rural households tend to opt for multiple sources of income generation, i.e. livelihood diversification ${ }^{1}$. In spite of that since $25^{\text {th }}$ March 2020, around 130 million people in India ${ }^{2}$ have become unemployed. Amongst 130 million, $40 \%$ are blue-collared jobs; which means these $40 \%$ are beyond the ambit of basic social security and benefits. While all kinds of jobs have been lost during the lockdown, jobs in farming sector have been rising. In May 2020, employment in farming increased by 1.4 million over its level in April 2020. In June 2020, the increase over May was a massive 11.8 million. While the average employment in farming in 2019-20 was 111 million, in June 2020 it was 130 million (CMIE, 2020). Usually, an increase in farming during economic stress is an indication of disguised unemployment.

Moreover, over 300 million people have not benefitted from the relief packages (CMIE, 2020).

The direct and indirect shocks and stresses of the COVID-19 crisis worldwide, although primarily considered a public health crisis, will have a much broader impact on the global

\footnotetext{
${ }^{1}$ As defined by Ellis (2000), livelihood diversification is the process by which rural households construct a growingly diverse portfolio of activities and assets in order to survive and to improve their standard of living. ${ }^{2}$ As of $1^{\text {st }}$ January 2020, the population of India was estimated to be 1,387,297,452 (according to www.countrymeters.info accessed on $7^{\text {th }}$ July 2020)
} 
economy. The worldwide socio- economic disruptions will not only diminish the well-being and livelihoods of people, but also undermined the social nets, markets and food security on which life depends. Both lives and livelihoods are and will be at risk from this pandemic. The socio-economic as well cultural and political repercussions arising from the lockdown, job loss, travel bans, disruptions in supply chain etc. have a twofold impact on lives and livelihoods of people and communities; one is the immediate impact and the other is the long term disruptions (www.livelihoodcentres.org accessed on $15^{\text {th }}$ June 2020).

However, any kind of shock tends to reinforce the existing socio-economic-political and environmental stresses, problems and inequalities. Therefore, even though COVID-19 is a pandemic, it has the capacity to affect different communities differently due to the inherent differential vulnerability. Impoverished people are usually less able to invest in risk-reducing measures. The lack of access to insurance and social protection means that people in poverty are often forced to use their marginally limited assets to buffer losses arising from shocks and stresses, which drives them into further poverty. Poverty is therefore both a cause and consequence of such disastrous events (Wisner et al., 2004). In various academic, political and economic domain, it has already been widely discussed how the recovery from the pandemic needs a more critical locale lens. Moreover, the geography of inequality expresses itself at a wide scale- temporally and spatially: between regions and countries, within countries and inside cities and localities (UNISDR, 2015a). Taking this idea of locale lens forward, the next sections of this paper will attempt to explore the COVID-19 and livelihood narratives in Indian Sundarban region.

\section{INDIAN SUNDARBANS: AN OVERVIEW}

The Indian Sundarbans Delta (ISD) is spread over about $9630 \mathrm{~km}^{2}$ between $21^{\circ} 40^{\prime} 04^{\prime \prime} \mathrm{N}$ and $22^{\circ} 09^{\prime} 21^{\prime \prime} \mathrm{N}$ latitude, and $88^{\circ} 01^{\prime} 56^{\prime \prime} \mathrm{E}$ and $89^{\circ} 06^{\prime} 01^{\prime \prime} \mathrm{E}$ longitude. This is the smaller and western part of the complete Sundarbans delta; around $60 \%$ of the delta region comes under the administrative boundary of Bangladesh. Indian Sundarban is an immense archipelago ${ }^{3}$ situated between the vast Bay of Bengal in the south and the fertile plains of Bengal in the north. This active delta region, created by the confluence of the rivers Ganges, Meghna,

\footnotetext{
${ }^{3}$ A part of Ganga- Brahmaputra- Meghna Delta (GBM Delta), this Indian Sundarban Delta region consists of 4200 square kilometers of forested area and 5400 square kilometers of non-forested areas that border the north and north-western part of the forests. There are currently 100 islands in the Indian Sundarbans Delta, of which 46 are forested and the rest 54 islands are variably inhabited. Indian Sundarbans is not an administrative unit; it is essentially a distinct eco-geographical region. However, administratively this area is constituted by 6 blocks of North-24 Parganas and 13 blocks of South-24 Paraganas districts in West Bengal, India. All these 54 islands are inhabited by 4.5 million people (Census 2011).
} 
Brahmaputra, and their innumerable distributaries, comprises of an intricate network of tidal channels and islands, the land being still under formation. Geographically and ecologically sensitive, this region has been recognized as the world's largest contiguous mangrove delta, a world heritage site, Ramsar site and also a biosphere reserve. The Indian Sundarbans Delta is bounded by the Ichamati-Raimangal River in the east, by the Hugli River in the west, by the Bay of Bengal in the south, and the Dampier Hodges line drawn in 1829-1830 in the north. Always in the headlines for the breathtaking natural beauty of the mangroves and the numerous flora and fauna (including Royal Bengal Tigers, crocodiles, and sharks), this place is also a home for over 4.5 million people. In absence of any major industrial area, this region is mostly dependent on rain-fed agriculture, fishing, and aquaculture.

\section{AIMS AND OBJECTIVES:}

This paper attempts to explore the impact of COVID-19 outbreak and lockdown the livelihood choices and daily lives in the coastal rural stretches of Indian Sundarbans delta region. Main objectives are -

- To analyse major livelihoods (with characteristic features)

- To explore the impact of COVID-19 lockdown on their lives and livelihoods in terms of access to food, dietary changes, access to resources, income, education and some other additional factors.

\section{MATERIALS AND METHODS:}

\subsection{Data Sources:}

Mostly primary data has been used for this study. Primary data for the $1^{\text {st }}$ objective, i.e. analysis of major livelihoods, has been collected during fieldwork in the year 2018-19. Household survey has been conducted using questionnaire. For the $2^{\text {nd }}$ objective, i.e. the impact of COVID-19 and lockdown on lives and livelihoods, telephonic rapid assessment survey has been carried out in April 2020. Apart from that census data, Indian Meteorological data have been consulted along with existing literature.

\subsection{Research design:}

In this particular study, mixed method research design was employed to gain enough insight for achievement of the desired objectives. Within mixed method, exploratory sequential research design was employed. 


\subsection{Sample size and design:}

Through stratified random selection 150 households have been selected and interviewed in the first phase to get the profile of varied livelihoods. The stratification was on the basis of distance of household from coastline. In the later phase, telephonic survey was conducted for 120 households (rest of the households were not available for telephonic survey).

\subsection{Details of the area of study:}

Total four villages have been selected for the study. Two villages selected from Sagar Island of SW Sundarbans are Beguakhali and Mahishamari, located near the south-western fringe of this island. The other two villages selected from Mousuni Island are Kusumtala and Baliara. These four census villages ${ }^{4}$ from two different islands are constituted of a population mostly dependent on subsistence level livelihoods. The interviewed population does not have any indigenous origin. However, Sagar Island experiences a large influx of pilgrims during Makar Sankranti and also throughout the year.

Table 1: Demographic characteristics of selected villages

\begin{tabular}{|c|c|c|c|c|}
\hline Island & \multicolumn{2}{|c|}{ Sagar Island } & Mahishamari & Mousuni Island \\
\hline Village & Beguakhali & Sagar & Namkhana & Namkhana \\
\hline Block & Sagar & Sagara & Mousuni \\
\hline Gram Panchayat & Gangasagar & Gangasagar & 711 & 921 \\
\hline Total household & 1074 & 539 & 3,756 & 4350 \\
\hline Total population & 5683 & 2890 & 1917 & 2200 \\
\hline Male population & 2911 & 1503 & 1,839 & 2150 \\
\hline Female population & 2772 & 1,387 & 2018 & 5957 \\
\hline Total no. of literates & 3854 & 1115 & 2042 & 2717 \\
\hline Total workers & 2360 & 1775 & 3621 & 5955 \\
\hline Total non-workers & 3323 & & & \\
\hline
\end{tabular}

Source: Census of India 2011

\footnotetext{
${ }^{4}$ Census village refers to the revenue village which is recognized by the normal district administration. It has a definite surveyed boundary and it may have one or more hamlets. The entire revenue village is one unit (Census of India)
} 


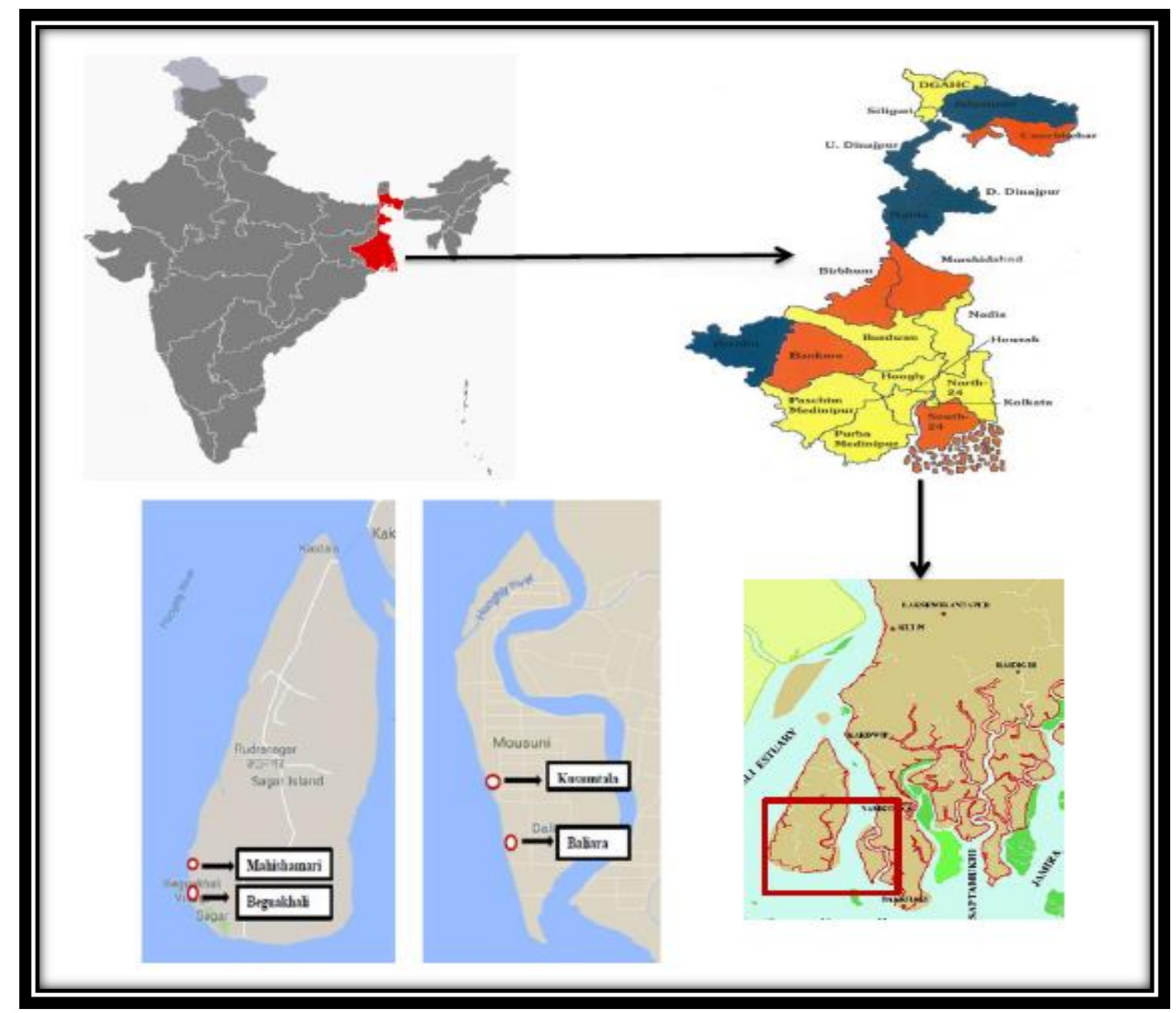

Fig.1: Location of study areas

\section{DISCUSSION:}

\subsection{Livelihood profile of Households $(H H)$ :}

Primarily, livelihood options are quite limited in the terrains of Indian Sundarbans; a large majority of the population is dependent on agriculture, fishing and other natural resource based options. Agricultural and non-agricultural labours constitute a percentage of the population. Around $24 \%$ of the population was identified as cultivators in Census of India 2001; however, no exact figures were found for fishermen population (Census 2001). As identified during the household survey, agriculture and fishing constitute the majority of the primary means of livelihood. In Sagar Island, $30 \%$ of the interviewed population is engaged in agriculture; the percentage is $17.8 \%$ in Mousuni Island. Inland and marine fishermen population constitutes around 26.7\% in Sagar Island and 44.5\% in Mousuni Island. 


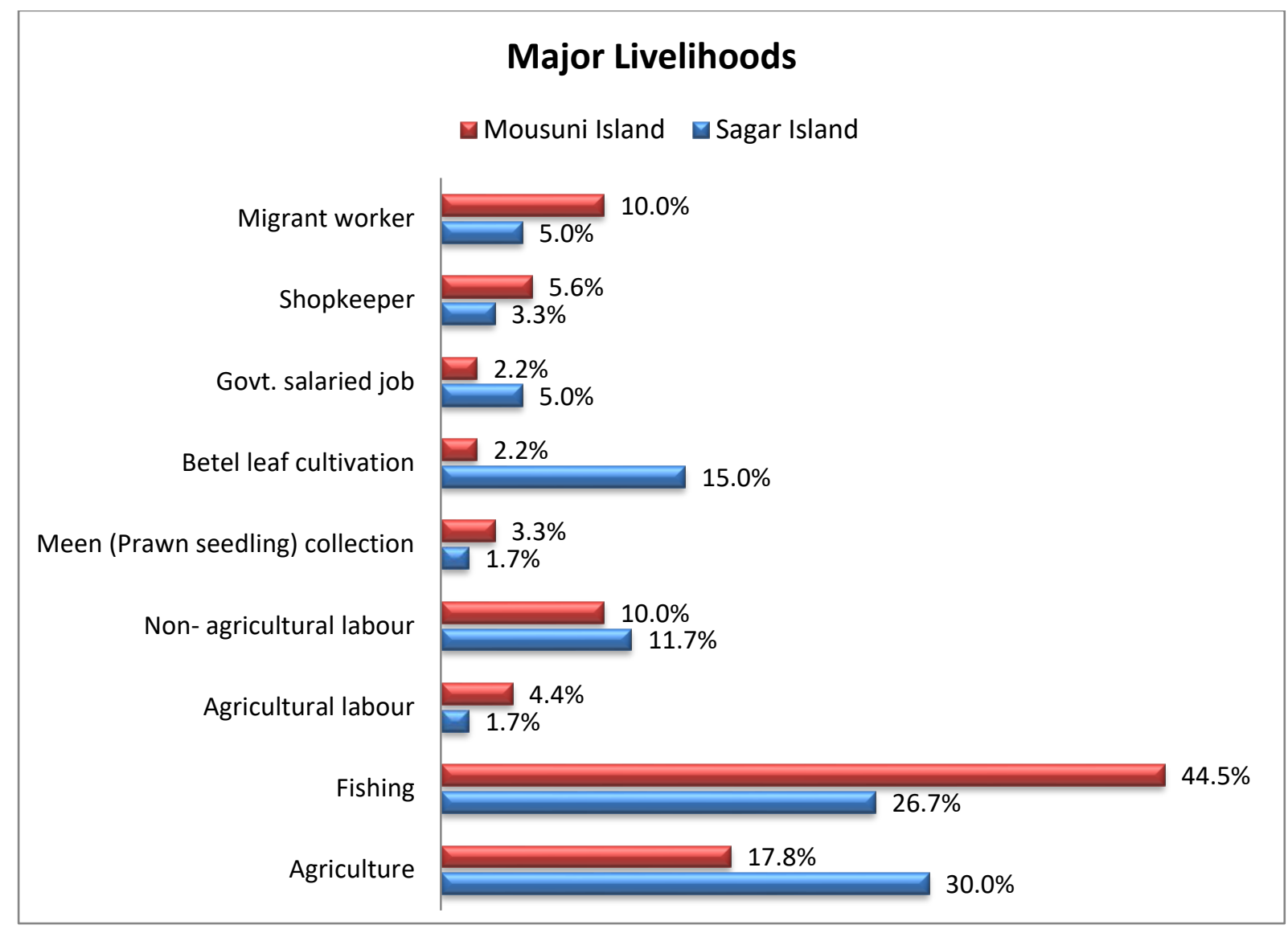

Source: Primary Survey

Fig.2: Major livelihood options identified in selected villages

Around $4.4 \%$ and $10 \%$ of the sample population of Mousuni Island are engaged as agricultural and non- agricultural labours respectively. In Sagar Island, agricultural labours and non-agricultural labours constitute $1.7 \%$ and $11.7 \%$ of the sample population. A small percentage of population in both the islands is engaged in prawn seedling collection, government salaried jobs and shop keeping. Betel leaf cultivation is a particularly significant livelihood strategy in Sagar Island (15\% of the sample). Around $10 \%$ of the sample households have migrant earning member in Mousuni Island; whereas, the proportion is 5\% in Sagar Island. Interestingly, a large proportion of the livelihood options found in the study area are quite seasonal in nature; therefore, it was found that $70 \%$ of the surveyed $\mathrm{HH}$ is engaged in secondary economic activity in Mousuni Island. However, the proportion is $40 \%$ in Sagar Island. A small percentage of $\mathrm{HH}$ is involved in fishing as a secondary means of livelihood; mostly inland fishing accounts for $10 \%$ and $9 \%$ of the secondary livelihood in Sagar Island and Mousuni Island respectively. A considerable section of $\mathrm{HH}$ is engaged as agricultural labour in Mousuni Island (7.8\%) and in Sagar Island (5\%). 
Table 2: Secondary means of livelihoods in surveyed population

\begin{tabular}{|c|c|c|}
\hline Secondary livelihood & Sagar island & Mousuni island \\
\hline No Secondary Livelihood & $60 \%$ & $30 \%$ \\
\hline Fishing & $10 \%$ & $9 \%$ \\
\hline Agricultural labour & $5 \%$ & $7.8 \%$ \\
\hline Non- agricultural labour & $10 \%$ & $10 \%$ \\
\hline Prawn seedling collection & $10 \%$ & $30 \%$ \\
\hline Crab catching & NA & $3.3 \%$ \\
\hline Migrant worker & $5 \%$ & $10 \%$ \\
\hline
\end{tabular}

Source: Primary Survey

A substantial proportion of $\mathrm{HH}$ is engaged in prawn seedling collection in Mousuni Island (30\%). A substantial population has been reported to migrate to cities in monsoon for daily wage jobs (10\% in Mousuni and 5\% in Sagar Island).

\subsection{Characteristic features and challenges of livelihoods in Sundarbans:}

A wide range of characteristic features of each of the livelihood strategies and myriad challenges associated with it were identified from the survey. As the economic activities are mostly natural resource and climate dependent, climatic and anthropogenic shocks and stresses play a significant role in the structural and functional integrity of the activities. The challenges associated with the activities are also multifaceted and it covers a wide spectrum of determining factors, including natural, climatic, economic, social, political and cultural aspects, some of which exclusively unique to the terrain. Tidal flooding, embankment breaches ${ }^{5}$, increasing salinity are highly site-specific factors of this terrain that directly influence the livelihood activities. A critical assessment of the livelihood characteristics and challenges faced by the islanders provide valuable insight regarding the triggers of vulnerability. Daily stressors, such as, tidal flooding, lack of employment, natural resource dependence, difficult modes of transport, lower income rate, coastal erosion, and increased salinity etc. provide a strong platform for shocks like COVID-19 to wreak havoc.

\footnotetext{
${ }^{5}$ The lifeline of Sundarbans is a $3500 \mathrm{~km}$ long embankment. It protects the low-lying land from saline water ingress during tide and storms. Thus, during storms or high tides the embankment breaches often inundate the villages, causing property loss.
} 
Table 3: Characteristic features of different economic activities as identified during survey

\begin{tabular}{|c|c|}
\hline Livelihood Options & Characteristic Feature \\
\hline Agriculture & $\begin{array}{l}\text { - Rain-fed mono-cropping of rice, brinjal, cauliflower, pulses, } \\
\text { chilies, potato, tomato etc. } \\
\text { - In spite of the salinity problem, Salt resistant varieties were not } \\
\text { found to be cultivated in the survey } \\
\text { - Decreasing cultivable land due to erosion and salinity } \\
\text { - } \text { Monsoon rainfall variability }\end{array}$ \\
\hline Fishing & $\begin{array}{l}\text { - Inland and marine fishing } \\
\text { - Fishing season: June- October/ November } \\
\text { - Fish drying: December- May } \\
\text { - } \quad \text { Boats are lend by middlemen on contract basis } \\
\text { - Tend to ignore "Fishermen alert" issued by IMD } \\
\text { - Lack of access to insurance and permit }\end{array}$ \\
\hline Non-agricultural labour & $\begin{array}{l}\text { - Employed in Mahatma Gandhi National Rural Employment } \\
\text { Guarantee Act }{ }^{6} \text { projects } \\
\text { - Engaged in the ongoing embankment construction/ } \\
\text { maintenance works } \\
\text { - Mostly irregular employment } \\
\text { - Opportunity of employment away from home }\end{array}$ \\
\hline Agricultural Labour & $\begin{array}{l}\text { - Decreasing agricultural activity in the adjoining islands } \\
\text { - Mechanization of agricultural activity in other agro-ecological } \\
\text { region } \\
\text { - Demand for manual labour due to non-mechanized form of } \\
\text { cultivation }\end{array}$ \\
\hline Betel vines cultivation & 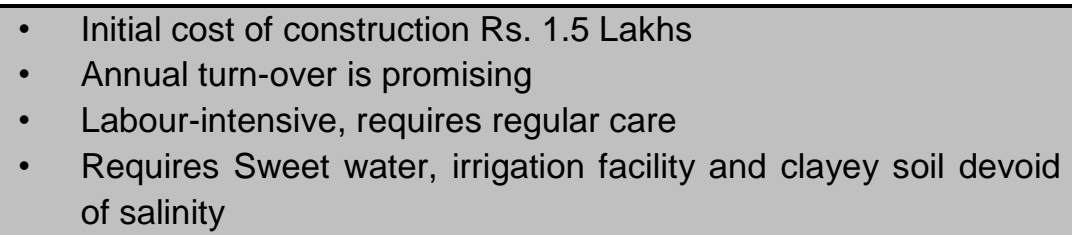 \\
\hline $\begin{array}{l}\text { Prawn seedling collection } \\
\& \text { crab catching }\end{array}$ & $\begin{array}{l}\text { - Involvement of women and children of households } \\
\text { - Crabs are caught near the creeks of Sundarban Reserve } \\
\text { Forest }\end{array}$ \\
\hline Out-migration & $\begin{array}{ll} & \text { Intra-state mobility (Kolkata, Burdwan, Birbhum) } \\
\text { - } & \text { Inter-state mobility ( Kerala, Tamil Nadu, Karnataka) } \\
\text { - } & \text { Change in social fabric }\end{array}$ \\
\hline
\end{tabular}

Source: Primary survey

Thus, the existing socio-economic and environmental conditions are adverse enough for the islanders of the study area. Moreover, since $25^{\text {th }}$ March 2020, lockdown has created a major disruption starting from restricted movement of people and lack of livelihood options to shortage of essential supplies in remote corners of the country including fringe villages

\footnotetext{
${ }^{6}$ The Mahatma Gandhi National Rural Employment Guarantee Act 2005 aims at enhancing the livelihood security of rural areas by ensuring 100 days of wage employment through unskilled manual labour in a financial year.
} 
(WWF, 2020). The next section attempts to explore the multidimensional impacts of COVID19 and lockdown on lives and livelihoods of the islanders of the study villages.

\section{IMPACT OF COVID-19 AND LOCKDOWN:}

As mentioned in the previous section, this whole terrain has a sense of marginality and uncertainty textured into the lives and livelihoods of the islanders. Through telephonic rapid assessment survey, several factors were taken into account. To keep to conversation brief and productive, short close-ended questions were asked. Questions leading to simple "Yes" or "No" were chosen to facilitate the information dissemination. In some exceptional cases, background information was gathered. The questions asked during telephonic conversations and concerned responses have been presented in tabular form (Table 4).

Table 4: Impact of COVID-19 lockdown on life and livelihood

\begin{tabular}{|c|c|c|c|c|}
\hline \multirow{2}{*}{$\begin{array}{l}\text { Questions asked during rapid assessment } \\
\text { survey (all the information are pertaining to } \\
\text { status of lives and livelihoods since } 25^{\text {th }} \\
\text { March 2020) }\end{array}$} & \multicolumn{2}{|c|}{ Sagar Island } & \multicolumn{2}{|c|}{ Mousuni Island } \\
\hline & Yes & No & Yes & No \\
\hline Do you have any steady income? & $41.7 \%$ & $58.3 \%$ & $33.4 \%$ & $66.6 \%$ \\
\hline $\begin{array}{l}\text { Do you have employment through } \\
\text { MGNREGA? }\end{array}$ & - & $100 \%$ & - & $100 \%$ \\
\hline Do you have access to ration? ${ }^{\prime}$ & $83.4 \%$ & $16.6 \%$ & $77.8 \%$ & $22.2 \%$ \\
\hline Did you reduce no. of meals per day? & $30 \%$ & $70 \%$ & $22.2 \%$ & $77.8 \%$ \\
\hline Did you reduce no. of items consumed? & $43.3 \%$ & $56.7 \%$ & $54.4 \%$ & $45.6 \%$ \\
\hline Do you have access to medical facilities? & $58.4 \%$ & $41.6 \%$ & $22.2 \%$ & $77.8 \%$ \\
\hline Can you maintain social distancing? & $16.7 \%$ & $83.3 \%$ & $13.4 \%$ & $86.6 \%$ \\
\hline \multirow{3}{*}{$\begin{array}{l}\text { Did you have to borrow cash? } \\
\text { - Borrowed from moneylender: } \\
\text { - Borrowed from relatives/ friends: }\end{array}$} & $26.6 \%$ & $73.4 \%$ & $35.5 \%$ & $64.5 \%$ \\
\hline & $10 \%$ & $\overline{N A}$ & $23.3 \%$ & $\overline{N A}$ \\
\hline & $16.6 \%$ & $\overline{N A}$ & $12.2 \%$ & $\overline{N A}$ \\
\hline Is there chance of school drop-out? & $16.7 \%$ & $83.3 \%$ & $22.2 \%$ & $77.8 \%$ \\
\hline \multirow[t]{2}{*}{ Is there any postponement of marriages? } & \multicolumn{2}{|c|}{ Scheduled marriages:10 } & \multicolumn{2}{|c|}{$\begin{array}{c}\text { Scheduled } \\
\text { marriages:24 }\end{array}$} \\
\hline & $80 \%$ & $20 \%$ & $79.2 \%$ & $20.8 \%$ \\
\hline $\begin{array}{l}\text { Do you have seed for next season of } \\
\text { farming? } \\
\text { (restricted to HH engaged in agriculture) }\end{array}$ & $16.7 \%$ & $83.3 \%$ & $13.4 \%$ & $86.6 \%$ \\
\hline Can you sell products in local market? & $56.7 \%$ & $43.3 \%$ & $35.5 \%$ & $64.5 \%$ \\
\hline Can you send perishable items to town? ${ }^{8}$ & $26.6 \%$ & $73.4 \%$ & - & $100 \%$ \\
\hline Did you face difficulty in harvesting? & $70 \%$ & $30 \%$ & $77.8 \%$ & $22.2 \%$ \\
\hline
\end{tabular}

Source: Primary survey

\footnotetext{
${ }^{7}$ As reported by the respondents, through Public Distribution System food grains are available free of cost. However, other essential items (baby food, medicines etc.) are not available due to disruption in the supply chain and travel bans.

${ }^{8}$ Perishable items exported from this region to town markets are flowers, vegetables, fish, and fruits.
} 
A massive $58.3 \%$ and $66.6 \%$ of the respondent $\mathrm{HH}$ of Sagar Island and Mousuni Island do not have any steady income since $25^{\text {th }}$ March 2020. Evidently, travel ban, lack of labour force, social distancing norms and complete disruption of all major economic activities across India have triggered this situation. Moreover, the fishers haven't been able to venture into the sea since end of March and are quite understandably concerned about the 45-day annual fishing ban in line with the fish breeding season, coming into force along the east coast of India from mid-April to $18^{\text {th }}$ June. All projects and employment opportunities have been ceased since the lockdown 1.0, leading to zero employment through this scheme. However, the majority of islanders have reported to have access to free ration through Public Distribution System. Moreover, some of the islanders have small backyard gardens where little bit of vegetable is grown. Thus, in Mousuni Island locally potatoes, onions, bitter gourds, snake gourds, drumsticks, fish are available; as export to town markets is not possible during lockdown, all the produce of the island is being sold in the local market. Therefore, the islanders are not yet starving. There is a reduction in the number of meals consumed per day in both the islands; the migrant families, landless households and households of older people are facing the scarcity of food to some extent. There is a dearth of cash inflow; therefore, the local economy is slowly succumbing. Around $43.3 \%$ and $54.4 \%$ of the $\mathrm{HH}$ of Sagar and Mousuni Islands reported a reduction in the no. of items in meal. A substantial $77.8 \% \mathrm{HH}$ of Mousuni island reported about lack of medical facilities. As the islands are geographically isolated from the mainland, disruption in transportation, and travel ban have become a major issue. Around $85 \% \mathrm{HH}$ of both the islands could not effectively maintain social distancing, mostly due to single room huts and space crunch. A proportion of $\mathrm{HH}$ have already borrowed cash for sustenance from moneylenders and relatives. However, sell of liquid asset was not yet reported. In Sagar and Mousuni Island, respectively, $16.2 \%$ and $22.2 \%$ of the respondents predicted a possibility of discontinuation of education of the kids. Moreover, more than $60 \%$ of the $\mathrm{HH}$ declared that they cannot afford online education. There have been 10 and 24 scheduled marriage ceremonies in the surveyed $\mathrm{HH}$ in Sagar and Mousuni Island. Around $80 \%$ of the marriages have been postponed and rest has experienced a major alteration in terms of expenses and invitees. Around $85 \%$ do not have any seeds left for next farming season. A small proportion of these $\mathrm{HH}$ have consumed the stock during lockdown. In Sagar Island, the local market is still comparatively more active than that in Mousuni Island. Sell of local produce in local market yields lesser profit compared to sell in town markets. Due to disruption in supply chain, local perishable goods cannot be exported to town markets. Fish, betel leaves and prawn seedlings are exported internationally from this 
region; unfortunately, since $25^{\text {th }}$ March, there has not been any export. The prawn seedlings and crabs are initially sold to middlemen; afterwards, prawn seedlings are grown locally for around 2 weeks then sold to prawn fisheries. The crabs are segregated and exported internationally via Kolkata (the state capital of West Bengal). Due to market closure, cease of international flights and waterways, and movement restrictions the export of these items has been stopped; thus, local prices have dropped, leading to loss of income. Even due to lack of labour availability and transport ban the aquaculture farms are experiencing huge loss. Harvest from agricultural field has faced immense problem as well.

\section{CONCLUSION:}

Apart from immediate effects of joblessness, lack of access to resources, lack of flow of remittances, socio-political uncertainty, this COVID-19 lockdown can have long term impact on the health and education status as well. The agriculture and fishing sector will have to provide sustenance and livelihood to the people who are returning from cities and abroad as a result of the COVID-19 pandemic. This unusual reverse flow of labour from urban to rural areas creates additional pressure on available farm land. There have been reports of increased dependence on forest resources for immediate income generation. However, it makes them susceptible to tiger attack and harassment as well. Therefore, better management of local resources to create a notion of sufficiency is needed. Ensuring workplace safety, social protection and risk insurance can have crucial contribution in safeguarding the vulnerable population. Provision of ration, medicines, and personal care goods from Government as well as NGOs can have significant contribution in reducing the plight of the islanders. Direct Bank Transfer of cash depending on level of vulnerability can be a useful tool as well. Moreover, development and implementation of comprehensive site-specific economic and resilience development programme aimed towards building self-reliance for local economies, local food systems, and on- and off-farm activities need to be encouraged.

As shocks like COVID-19 pandemic and lockdown eventually reinforces the existing inequalities and lack of opportunities, strengthening the system as a whole is of utmost importance. As popularly said during the lockdown "We are in the same storm, but not in the same boat", the communities experiencing plight needs to be assessed locally for identification of triggers of vulnerability.

In this paper, the information collected from the respondents provides an initial rapid assessment survey report. Further, advanced phases of survey can generate useful information to identify scope of policy intervention. 


\section{REFERENCES:}

Beltrami, S. (2020). How to Minimise the Impact of Coronavirus on Food Security.[Online] World Food Programme Insight.

FAO. (2014). State of Food Insecurity in the World 2013: The Multiple Dimensions of Food Security. FAO.

General, R. (2001). Census Commissioner of India. 2001. Census of India, 200, 2001-26p.

INDIA, P. (2011). Census of India 2011 Provisional Population Totals. New Delhi: Office of the Registrar General and Census Commissioner.

Long term cost of lockdown by Mahesh Vyas (2020) accessed on $11^{\text {th }}$ July 2020: $\mathrm{URL}=\mathrm{https}: / / \mathrm{www} . \mathrm{cmie} . \mathrm{com} /$ kommon/bin/sr.php?kall=warticle\&dt=2020-05$\underline{12 \% 2010: 21: 58 \& \mathrm{msec}=653}$

Periodic Labour Force Survey Report $(2017-18)$ accessed on $9^{\text {th }}$ July 2020: URL $=$ http://www.mospi.gov.in/sites/default/files/publication_reports/Annual\%20Report\%2C \%20PLFS\%202017-18_31052019.pdf

Robert, C., \& Conway, G. (1991). Sustainable rural livelihoods: practical concepts for the 21st century. IDS Discussion, 296.

Scoones, I. (2009). Livelihoods perspectives and rural development. The journal of peasant studies, 36(1), 171-196.

Timeline of WHO's response to COVID-19 accessed on $2^{\text {nd }}$ July 2020: URL=https://www.who.int/news-room/detail/29-06-2020-covidtimeline

UNISDR, C. (2015). The human cost of natural disasters: A global perspective.

Wisner, B., Gaillard, J. C., \& Kelman, I. (2012). Framing disaster: theories and stories seeking to understand hazards, vulnerability and risk. In Handbook of hazards and disaster risk reduction (pp. 47-62). Routledge.

World Employment and Social Outlook - Trends 2018 accessed on 10 ${ }^{\text {th }}$ July 2020: $\mathrm{URL}=$ https://www.ilo.org/wcmsp5/groups/public/---dgreports/---dcomm/--publ/documents/publication/wcms_615594.pdf

Worldometer Corona Virus Update Live Accessed on $2^{\text {nd }}$ July 2020:

$\mathrm{URL}=\mathrm{https}: / / \mathrm{www}$. worldometers.info/coronavirus/?utm_campaign=homeAdvegas 1

WWF India's COVID emergency response in Sundarbans accessed on 10th July 2020: URL= https://www.wwfindia.org/news_facts/feature_stories/wwf_india_s_covid_emergency _response_in_sundarbans.cfm 